\title{
Pseudonecrocarcinus eichhorni n. sp. (Brachyura, Raninoida, Paranecrocarcinidae) from the Late Cretaceous (Coniacian) of Montana (USA)
}

Pseudonecrocarcinus eichhorni n. sp. (Brachyura, Raninoida, Paranecrocarcinidae) del Cretácico tardío (Coniaciano) de Montana (EUA)

Torrey Nyborg ${ }^{1}$, Alessandro Garassino ${ }^{1}$, Gianni Pasini ${ }^{2}$, Francisco J. Vega ${ }^{3, *}$

${ }^{1}$ Department of Earth and Biological Sciences, Loma Linda University, Loma Linda, CA 92350, USA.

${ }^{2}$ Via Alessandro Volta 16, 22070 Appiano Gentile (Como), Italy.

${ }^{3}$ Instituto de Geología, Universidad Nacional Autónoma de México, Ciudad Universitaria, Coyoacán, CDMX, 04510, Mexico.

* Corresponding author: (F. J. Vega) vegver@unam.mx

\begin{abstract}
The new species, Pseudonecrocarcinus eichhorni (Paranecrocarcinidae Fraaije, Van Bakel, Jagt and Artal, 2008) from the Late Cretaceous (Coniacian) of Montana is herein described. This new species represents the second report for the genus from the Late Cretaceous of USA.
\end{abstract}

Keywords: Crustacea, Decapoda, taxonomy, Late Cretaceous, Montana, Western Interior seaway, USA.

\section{RESUMEN}

La especie nueva Pseudonecrocarcinus eichhorni (Paranecrocarcinidae Fraaïje, Van Bakel, Jagt and Artal, 2008) del Cretácico Tardio (Coniaciano) de Montana es descrita aquí. Ésta nueva especie representa el segundo reporte para el género, del Cretácico Tardio de los EUA.

Palabras clave: Crustacea, Decapoda, taxonomía, Cretácico Tardío, Montana, Mar Interior Oeste, EUA.

\section{How to cite this article:}

Nyborg, T., Garassino, A., Pasini, G., Vega, F.J., 2021, Pseudonecrocarcinus eichhorni n. sp. (Brachyura, Raninoida, Paranecrocarcinidae) from the Late Cretaceous (Coniacian) of Montana (USA): Boletín de la Sociedad Geológica Mexicana, 73 (3), A281220. http://dx.doi.org/10.18268/ BSGM202lv73n3a281220

Manuscript received: August 7, 2020

Corrected manuscript received: October 1, 2020

Manuscript accepted: October 12, 2020

Peer Reviewing under the responsibility of Universidad Nacional Autónoma de México.

This is an open access article under the CC BY-NC-SA license(https://creativecommons.org/licenses/by-nc-sa/4.0/) 


\section{Introduction}

The Family Paranecrocarcinidae Fraaije, Van Bakel, Jagt and Artal, 2008 shows a North Atlantic-Western Tethyan distribution based upon the fossil record known to date. Indeed, earliest reports of representatives of paranecrocarcinid crabs have been recorded on both sides of the North Atlantic, and new occurrences have been reported through western Asia into Africa from the Late Cretaceous (see Schweitzer et al., 2016: fig. 13).

Subject of this paper is the description of a new species of paranecrocarcinid crab from the Late Cretaceous (late Coniacian) of Montana, representing the second record of the Paranecrocarcinidae from the Late Cretaceous of USA.

\section{Geological setting}

The sole specimen was found as talus at the base of a large (approximately 35 meter) vertical cut bank exposure at Mud Creek, west-central Montana (Figure 1). The most thorough work on these deposits was published by Cobban et al. (2005). They measured a section in the NW-NE and SW-NE section 11, T6N, R17E, Wheatland County, along the south side of Mud Creek on the Shawmut Anticline southeast of Harlowtown, Montana (Cobban et al., 2005). Their measured section and subsequent other measured sections and correlations match the locality where the specimen described herein was collected. The exposure consists of dark-gray clayey shale interbedded with 1-2 meter thick sandstone beds. Approximately 11 meters from the base of the exposure is a bed that forms a prominent south-dipping bench that correlates to the MacGowan bed (Cobban et al., 2005). The MacGowan bed forms a distinctive concretionary bed interpreted as having formed during a relative sea-level lowstand event of the Cretaceous Western Interior seaway and has been correlated as a sequence boundary within the marine section traced over much of west-central Montana and western Alberta (Cobban et al.,
1959, 2005).

The MacGowan bed lies disconformably on middle or lowermost upper Coniacian strata, and is overlain by mid to uppermost Coniacian beds (refer to Cobban et al., 2005 for more detailed stratigraphy). Fossiliferous limestone and dolostone concretions occur throughout this section. Since the specimen described herein was collected as talus at the bottom of the exposure, the exact locality cannot be pin-pointed; however the exposure as measured and correlated by Cobban et al. (2005) is from the Coniacian, based on the occurrence of the MacGowan bed in the sequence and biostratigraphically constrained inoceramid bivalves and ammonites collected at this locality and similar lithologic localities within west-central Montana (Cobban et al., 2005). This is the first fossil crab reported from these deposits.

\section{Systematic palaeontology}

Infraorder Brachyura Latreille, 1802

Section Raninoida Ahyong, Lai, Sharkey, Colgan and $\mathrm{Ng}, 2007$

Superfamily Necrocarcinoidea Förster, 1968 Family Paranecrocarcinidae Fraaije, Van Bakel, Jagt and Artal, 2008

\section{Genus Pseudonecrocarcinus Förster, 1968}

Type species: Necrocarcinus quadriscissus Noetling, 1881, by monotypy [Late Cretaceous (Maastrichtian), The Netherlands].

Other fossil species: Pseudonecrocarcinus biscissus Wright and Collins (1972), Late Cretaceous (Cenomanian), UK; P. digitatus (Wright and Collins, 1972), Late Cretaceous (Cenomanian), UK; $P$. eichhorni $\mathrm{n}$. sp. (herein); P. foersteri (Wright and Collins, 1972), Late Cretaceous (Cenomanian), UK; $P$. gamma (Roberts, 1962), Late Cretaceous (Campanian), USA; P. graysonensis (Rathbun, 1935), Early Cretaceous (Albian), USA; P. milbournei Collins, 2010, Late Cretaceous (Cenomanian), Nigeria; $P$. moseleyi (Stenzel, 1945), Early Cretaceous (Albian), 

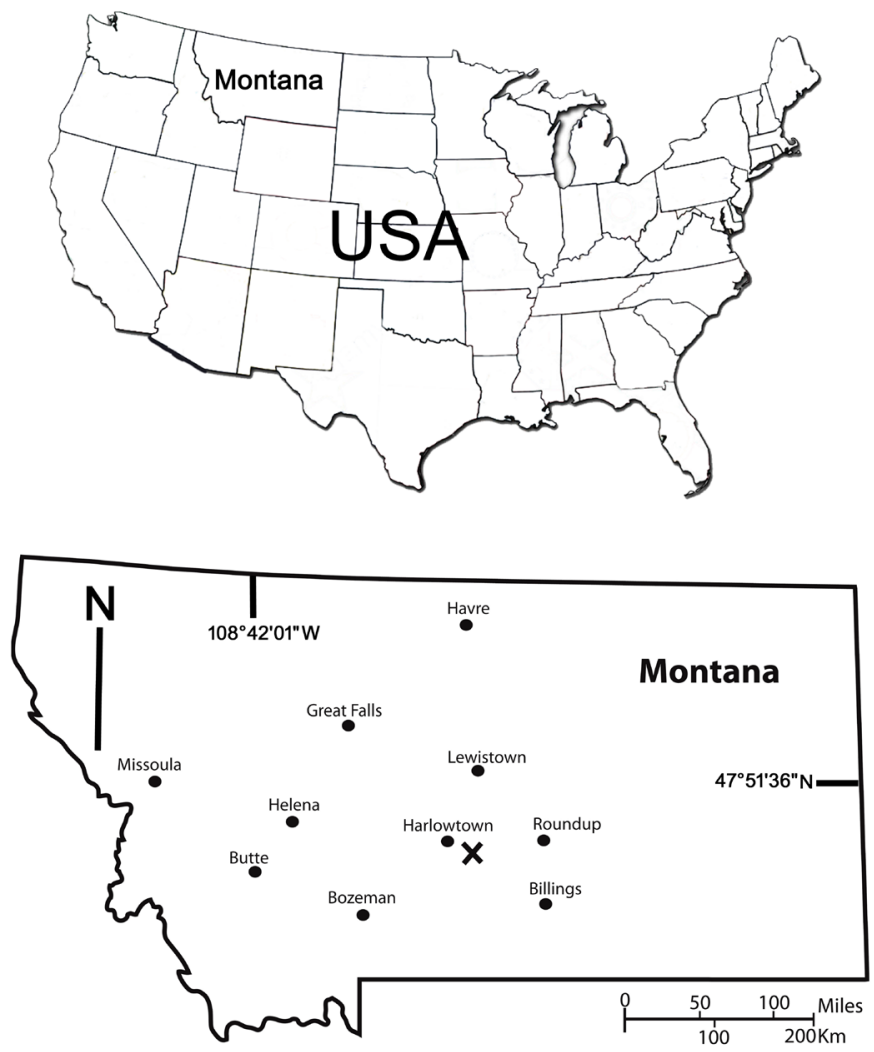

Figure 1 Generalized map of Montana State, USA showing major towns and location, marked by a X, where the specimen of Pseudonecrocarcinus eichhorni $\mathbf{n}$. sp. was collected.

USA; P. pusillus (Breton and Collins, 2011), Late Cretaceous (Cenomanian), France; P. scotti (Stenzel, 1945), Early Cretaceous (Albian), USA; $P$. vanbirgeleni Fraaije, 2002, Late Cretaceous (Maastrichtian), The Netherlands.

\section{Pseudonecrocarcinus eichhorni n. sp.}

Figures 2A and 2B

Diagnosis: Suboval carapace wider than long, uniformly covered with granules; carapace with large swellings on gastric, cardiac, and branchial regions; anterolateral margin with nine spines; posterolateral margin with one spine followed by smaller granulations decreasing posteriorly; one pair of postrostral slits.

Etymology: The species is named in honour of Connie Eichhorn who has collected numerous fossils in Montana, many of which have been published in the scientific literature.
Holotype: UWBM IP 114701 (UWBM IP $=$ The Burke Museum of Natural History and Culture, Invertebrate Paleontology Collections, University of Washington, Seattle, Washington State, USA).

Type locality: Bank exposure at Mud Creek, west-central Montana.

Material and measurements: One complete carapace in dorsal view (UWBM IP 114701 - carapace length: $16 \mathrm{~mm}$; carapace width: 19 $\mathrm{mm})$.

Description: Suboval carapace wider than long, weakly vaulted longitudinally, moderately flattened transversally; regions well defined; rostrum weakly projecting beyond orbits; postrostral region with two parallel longitudinal elongate slits, each ending in a distinct pit posteriorly forming a medial rounded elongate rim; front slightly downturned distally; frontal margin poorly preserved; rounded orbits forwardly directed; anterolateral 
margin rounded, convex with nine triangular protruding spines (including epibranchial tooth), slightly increasing in size posteriorly; posterolateral margin nearly straight, fringed with small spines, decreasing in size posteriorly; posterior margin slightly concave medially; dorsal carapace covered by granules uniformly arranged, larger on the metabranchial and intestinal regions; short deep branchiocardiac grooves, delimiting cardiac region; smooth epigastric region slightly depressed; postorbital region inflated frontally; postorbital and hepatic regions finely granulate, slightly depressed; hepatic region with one small tubercle near the lower of anterolateral margin; inflated protogastric regions with two distinct rounded equal tubercles; mesogastric region with two rounded stout tubercles, the anterior one larger; metagastric region with two deep gastric pits; cardiac region separated by gastric regions by wide depressed urogastric region; cardiac region rounded, inflated, with two equal tubercles ranged transversally; branchial regions moderately expanded laterally, convex, inflated,
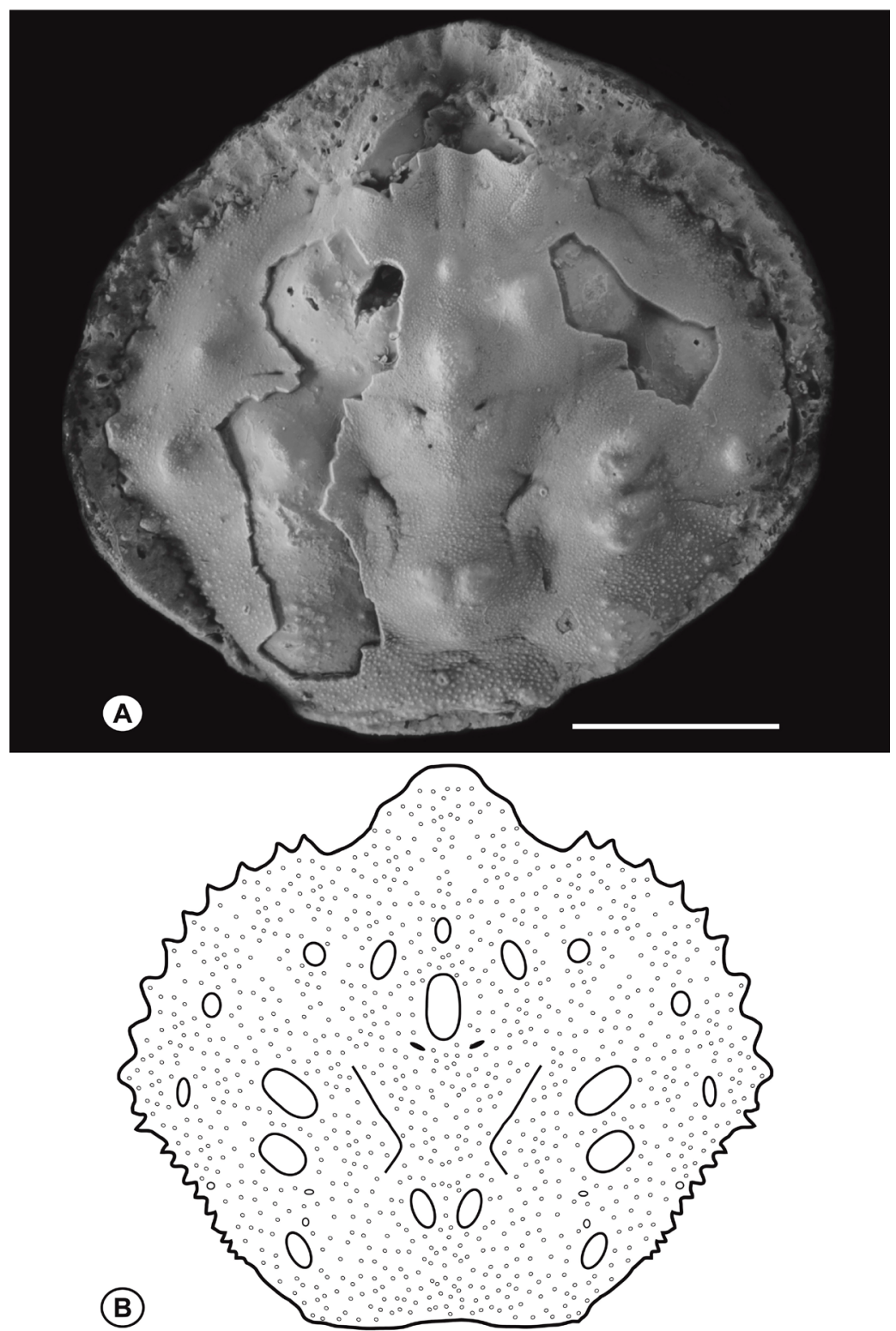

Figure 2 Pseudonecrocarcinus eichhorni n. sp., holotype UWBM IP 114701. A - Dorsal view. Scale bar equals 5 mm. B - Idealized line drawing of carapace. 
with rounded protuberances; epibranchial region with one tubercle; mesobranchial region with two contiguous tubercles ranged longitudinally, the anterior one slightly smaller; metabranchial region with one stout tubercle; flat, short, and granulate intestinal region.

\section{Discussion}

Based upon the close review of the Necrocarcinoidea Förster, 1968 by Schweitzer et al. (2016), the subfamily Paranecrocarcininae Fraaije, Van Bakel, Jagt and Artal, 2008, was elevated to the rank of family, including three genera: Paranecrocarcinus Van Straelen, 1936; Protonecrocarcinus Förster, 1968; and Pseudonecrocarcinus Förster, 1968. As reported by Schweitzer et al. (2016: 344, Tab. A2), this family is divided into two major clades: the first represented by Paranecrocarcinus with four species (P. balla Van Bakel, Guinot, Artal, Fraaije and Jagt, 2012; P. hexagonalis, Van Straelen, 1936; P. libanoticus Förster, 1968, and P. mozambiquensis Förster, 1970) having just one tubercle on the protogastric region, and the second represented by the genera Paranecrocarcinus and Pseudonecrocarcinus which share only one character, the presence of one tubercle on the epibranchial region between the cervical and secondary grooves. The main characters for each genus have been confirmed by Schweitzer et al., (2018: 12-14).

We can exclude the belonging of the studied specimen to Paranecrocarcinus in having two aligned tubercles in the protogastric region.

We can rule out the belonging of the studied specimen to Protonecrocarcinus including currently two species, $P$. ovalis (Stenzel, 1945) from the Early Cretaceous (Albian) of Texas (USA) and P. tuberosus Schweitzer, Feldmann, Kues and Bridge, 2017 from the Late Cretaceous (Turonian) of New Mexico (USA). The moderately flattened carapace, lacking of large swellings, the postrostral region with two parallel longitudinal elongate slits (vs. no slits in $P$. ovalis and $P$. tuberosus), the anterolateral margin with continuous and equal spines (vs. unequal spines separated by a notch in P. ovalis; equal spines and one larger spine in $P$. tuberosus), and the cardiac region with two equal tubercles (vs. one tubercle in $P$. ovalis and $P$. tuberosus) exclude the belonging of the studied specimen to Protonecrocarcinus.

We assign the studied specimen to Pseudonecrocarcinus in having granular carapace, with regions ornamented with large tubercles, anterolateral margins with numerous spines, posterolateral margin fringed with several small spines, and epibranchial region with one tubercle between the cervical and secondary grooves.

Based upon the list of the species of Pseudonecrocarcinus provided by Schweitzer et al., (2016: 362) four species are reported to date from the Early and Late Cretaceous of USA: P. gamma, P. graysonensis, P. moseleyi, and P. scotti.

Pseudonecrocarcinus graysonensis (=Necrocarcinus graysonensis) was described by Rathbun (1935: 45) from one sole incomplete carapace from the Early Cretaceous (Albian) of Texas (USA). The anterolateral margin with five spines and the cardiac region with one tubercle, distinguish this species from $P$. eichhorni n. sp.

Pseudonecrocarcinus moseleyi (=Necrocarcinus moseleyi) was described by Stenzel (1945: 441) from one incomplete carapace from the Early Cretaceous (Albian) of Texas (USA). The anterolateral margin with eight tiny tubercles, of which six occur anterior to the hepatic notch, three small tubercles grouped together with the high epibranchial tubercle, and smooth cardiac region distinguish this species from P. eichhorni n. sp.

Pseudonecrocarcinus scotti (=Necrocarcinus scotti) was described by Stenzel (1945: 445) from one complete carapace from the Early Cretaceous (Albian) of Texas (USA). The rostrum and the carapace with 17 swellings distinguish this species from P. eichhorni n. sp.

Pseudonecrocarcinus gamma (=Paranecrocarcinus gamma) was described by Roberts (1962: 182) from one incomplete carapace from the Late Cretaceous (Campanian) of New Jersey (USA). The anterolateral margin with four spines, the posterolateral margin with three spines, and the urogastric region with one median tubercle distinguish this species from P. eichhorni n. sp. 


\section{Conclusion}

Based upon the new species, the fossil record of Pseudonecrocarcinus Förster, 1968 includes to date 12 species, restricted from the Early Cretaceous (Albian) to Late Cretaceous (Maastrichtian). Pseudonecrocarcinus eichhorni $\mathrm{n}$. sp. represents the second report for the genus from the Late Cretaceous of USA.

\section{Acknowledgements}

We wish to thank Connie Eichhorn for donating the sole specimen described herein for research. We also wish to thank Ronald C. Eng, Geology and Paleontology Collections Manager, Burke Museum, for getting us a specimen catalogue number for the type specimen. Finally, we thank H. Karasawa, Mizunami Fossil Museum, Yamanouchi, Akeyo, Mizunami, Gifu (Japan) for careful review and criticism.

\section{References}

Ahyong, S.T., Lai, J.C.Y., Sharkey, D., Colgan, D.J., Ng, P.K.L., 2007, Phylogenetics of the brachyuran crabs (Crustacea: Decapoda): the status of Podotremata based on small subunit nuclear ribosomal RNA: Molecular Phylogenetics and Evolution, 45, 576-586. https://doi.org/10.1016/j. ympev.2007.03.022

Breton, G., Collins, J.S.H., 2011, New and rare Cenomanian crabs (Crustacea, Decapoda, Brachyura) from the Paris Basin (France), and a comparison with necrocarcinids, etyids and dynomenids from Devon (England): Neues Jahrbuch für Geologie und Paläontologie, Abhandlungen, 260, 141-156. https://doi. org/10.1127/0077-7749/2011/0166

Cobban, W.A., Erdmann, C.E., Lemke, R.W., Maughan, E.K., 1959, Revision of Colorado Group on Sweetgrass Arch, Montana:
American Association of Petroleum

Geologists, 43, 2786-2796. https://doi. org/ $10.1306 / 0$ bda5f5 1-16bd-11d 7 8645000102c1865d

Cobban, W.A., Dyman, T.S., Porter K.W., 2005, Paleontology and stratigraphy of upper Coniacianemiddle Santonian ammonite zones and application to erosion surfaces and marine transgressive strata in Montana and Alberta: Cretaceous Research, 26 (3), 429-449. https://doi.org/10.1016/j. cretres.2005.01.007

Collins, J.S.H., 2010, New species of crabs (Crustacea, Decapoda), one from the Middle Danian of Denmark, and three new species from the Upper Cretaceous of Nigeria: Bulletin of the Mizunami Fossil Museum, 36, 13-19.

Förster, R., 1968, Paranecrocarcinus libanoticus n. sp. (Decapoda) und die Entwicklung der Calappidae in der Kreide: Mitteilungen der Bayerischen Staatssammlung für Paläontologie und Historische Geologie, 8, 167-195.

Förster, R., 1970, Neue Dekapoden-Reste aus der Oberkreide von Moçambique, Norddeutschland und den bayerischen Alpen: Paläontologische Zeitschrift, 44 (34), 134-144. https://doi.org/10.1007/ bf02990633

Fraaije, R.H.B., 2002, New calappid crabs (Crustacea, Decapoda, Brachyura) from the Late Maastrichtian of the Netherlands: Journal of Paleontology, 76(5), 913-917.

Fraaije, R.H.B., Van Bakel, B.W.M., Jagt, J.W.M., Artal. P., 2008, New decapod crustaceans (Anomura, Brachyura) from mid-Cretaceous reefal deposits at Monte Orobe (Navarra, northern Spain), and comments on related type-Maastrichtian material: Bulletin de l'Institut Royal des Sciences Naturelles de Belgique (Sciences de la Terre), 78, 193-208.

Latreille, P.A., 1802, Histoire naturelle, générale et particulière des Crustacés et des Insectes. 
Ouvrage faisant suite à l'histoire naturelle générale et particulière, composée par Leclerc de Buffon, et rédigée par C.S. Sonnini, membre de plusieurs sociétés savantes. Familles naturelles des genres. Vol. 3. F. Dufart, Paris.

Noetling, F., 1881, Über einige Brachyuren aus dem Senon von Maestricht und dem Tertiär Norddeutschlands: Zeitschrift der Deutschen Geologischen Gesellschaft, 33, 357-371.

Rathbun, M.J., 1935, Fossil Crustacea of the Atlantic and Gulf Coastal Plain: Geological Society of America, 2, 1-160. https://doi. org/10.1130/spe2-pl

Roberts, H.B., 1962, The Upper Cretaceous decapod crustaceans of New Jersey and Delaware. In, H. G. Richards (ed.), The Cretaceous fossils of New Jersey: Bulletin of the New Jersey Division of Geology, 61, 163-192.

Schweitzer, C.E., Karasawa, H., Luque, J., Feldmann, R.M., 2016, Phylogeny and classification of Necrocarcinoidea Förster, 1968 (Brachyura: Raninoida) with the description of two new genera: Journal of Crustacean Biology, 36 (3), 338-372. https:// doi.org/10.1163/1937240x-00002432

Schweitzer, C.E., Feldmann, R.M., Karasawa, H.,
Luque, J., 2018, Part R, Revised, Volume 1, Chapter 8S: Systematic descriptions: Section Raninoida: Treatise Online, 113, 1-42.

Schweitzer, C.E., Feldmann, R.M., Kues, B.S., Bridge, E.K, 2017, New Decapoda (Axiidea, Anomura, Brachyura) from the Turonian of New Mexico, USA: Neues Jahrbuch für Geologie und Paläontologie, Abhandlungen, 284 (1), 89-115. https://doi.org/10.1127/ njgpa/2017/0654

Stenzel, H.B., 1945, Decapod crustaceans from the Cretaceous of Texas: The University of Texas Publication, 4401, 401-477.

Van Bakel, B.W.M., Guinot, D., Artal, P., Fraaije, R.H.B., Jagt, J.W.M., 2012, A revision of the Palaeocorystoidea and the phylogeny of raninoidian crabs (Crustacea, Decapoda, Brachyura, Podotremata): Zootaxa, 3215, 1-216. https://doi.org/10.11646/ zootaxa.3215.1.1

Van Straelen, V., 1936, Crustacés Décapodes nouveaux ou peu connus de l'époque Crétacique: Bulletin du Musée Royal d'Histoire Naturelle de Belgique, 12 (45), $1-49$.

Wright, C.W., Collins, J.S.H., 1972, British Cretaceous crabs: Palaeontographical Society Monographs, 126 (533), 1-113. 